\title{
Calibration Methods for Estimation of Reference Evapotranspiration in Morro Do Chapéu, Bahia, Brazil
}

\author{
Taiara Souza Costa ${ }^{1}$, Ramon Amaro de Sales ${ }^{2}$, Robson Argolo dos Santos ${ }^{3}$, Evandro Chaves de Oliveira ${ }^{4}$, \\ Dieimes Bohry ${ }^{5}$, Rodrigo Amaro de Salles ${ }^{6}$, Erli Pinto dos Santos ${ }^{3} \&$ Rosangela Leal Santos $^{1}$ \\ ${ }^{1}$ Departamento de Ciências Biológicas, Universidade Estadual de Feira de Santana, Feira de Santana, BA, Brazil \\ ${ }^{2}$ Departamento de Fitotecnia, Universidade Federal de Viçosa, Viçosa, MG, Brazil \\ ${ }^{3}$ Departamento de Engenharia Agrícola, Universidade Federal de Viçosa, Viçosa, MG, Brazil \\ ${ }^{4}$ Instituto Federal de Educação, Ciência e Tecnologia do Espírito Santo, Campus Itapina, Colatina, ES, Brazil \\ ${ }^{5}$ Centro de Ciências e Tecnologias Agropecuárias, Universidade Estadual do Norte Fluminense Darcy Ribeiro, \\ Campos dos Goytacazes, RJ, Brazil \\ ${ }^{6}$ Centro de Ciências Agrárias e Engenharias, Universidade Federal do Espírito Santos, Alegre, ES, Brazil \\ Correspondence: Ramon Amaro de Sales, Departamento de Fitotecnia, Universidade Federal de Viçosa, Viçosa, \\ MG, CEP: 36570900, Brazil. Tel: 55-31-3899-2642; 55-31-3899-2681. E-mail: ramonamarodesales@gmail.com
}

Received: January 19, 2019 Accepted: February 23, $2019 \quad$ Online Published: April 15, 2019

doi:10.5539/jas.v11n5p82 URL: https://doi.org/10.5539/jas.v11n5p82

\begin{abstract}
The objective of this work was to calibrate and to validate the methods of Camargo, Hargreaves and Samani, and Priestley and Taylor, according to the Penman-Monteith model, for the estimation of reference evapotranspiration (ETo), in the four seasons of the year for the municipality of Morro do Chapéu, Bahia. Climatological data from the conventional meteorological station belonging to the National Institute of Meteorology (INMET) were used, in the period of 18 years (2000-2018). The first 16 years were considered to adjust the parameters. The years of 2016 and 2017 were assigned as independent data to validate the adjustments. To analyze the results, it was used the root mean square error (RMSE in $\mathrm{mm} \mathrm{d}^{-1}$ ), coefficient of determination $\left(\mathrm{R}^{2}\right)$, systematic error (BIAS in $\mathrm{mm} \mathrm{d}^{-1}$ ), and Willmott's concordance index. After adjusting the parameters, the three methods improved their performance in the estimation of ETo, however, the Camargo method presented high values of RMSE, reaching $0.41 \mathrm{~mm} \mathrm{~d}^{-1}$ during the spring. It is concluded that the calibrated methods of Hargreaves and Samani, and, Priestley and Taylor can be recommended for the estimation of the reference evapotranspiration, for planning and execution of irrigation projects in the municipality, regardless of the season.
\end{abstract}

Keywords: calibration, irrigation, penman-monteith FAO 56, semi-arid

\section{Introduction}

Estimation of crop water requirements is an important aspect to be considered in agricultural planning and, consequently, has constituted a research area of considerable interest by the scientists involved with studies related to irrigation management and agrometeorology worldwide (Nova et al., 2006). This is because agricultural activities are highly dependent on climatic variables, making it a determinant factor for agricultural production (Sales et al., 2018a).

Reference evapotranspiration is the way in which the water of the terrestrial surface passes to the atmosphere in the vapor state, playing an important role in the hydrological cycle, which allows to know the water balance of the soil and the evapotranspiration of crops (Bezerra et al., 2010; Fernandes et al., 2012; Sales et al., 2016). In terms of irrigation management, for the correct depth of applied water, it is required to determine the crop evapotranspiration (ETc). The ETc is given by the product between the reference evapotranspiration (ETo) and the crop coefficient (Kc), which varies according to the crop and its phenological stage (Allen et al., 1998).

In regions with specific climatic characteristics at least one method that estimates ETo with good accuracy is desirable. Therefore, the Penman-Monteith method (Allen et al., 1998) was parameterized using the FAO Bulletin 56 (Food and Agriculture Organization of the United Nations) to determine the ETo reliably. This method is widely used to estimate evapotranspiration (Srivastava et al., 2018), but it requires a large number of 
climatological variables, which may be unavailable in some meteorological stations, with basic data such as temperature, humidity and wind speed (Carvalho et al., 2015; Tanaka et al., 2016).

Due to the requirement of many input variables, the model proposed by the FAO Bulletin 56 becomes, in many cases, inapplicable to estimate ETo. However, there are several empirically based methods that can be calibrated and validated for climatic conditions of interest, which use a few meteorological variables.

In the municipality of Morro do Chapéu, Bahia, the study of evapotranspiration is still scarce. Estimating the ideal ETo method for the climatic conditions of the region becomes very important since farmers have invested in irrigation systems for several crops, like plum, apple, strawberry, and grape.

The objective of this study was to calculate the ETo using four different ETo methods, and to make calibration and validation, between three simpler alternative ETo methods and the FAO-56 Penman-Monteith method, for the seasons of the year in Morro do Chapéu, Bahia, Brazil.

\section{Material and Methods}

This study was carried out in the municipality of Morro do Chapéu, with a total area of 5,744,968 $\mathrm{km}^{2}$, located in the semi-arid region of Bahia State (Latitude $11^{\circ} 55^{\prime} \mathrm{S}$, Longitude $41^{\circ} 17^{\prime} \mathrm{W}$ and altitude of $1017 \mathrm{~m}$ ), which is located in the Northeast region of Brazil (Figure 1). According to Lobão et al. (2011), the climate of the municipality is characterized as dry to sub-humid and semi-arid, with the rainy season concentrated in the months of November to January.

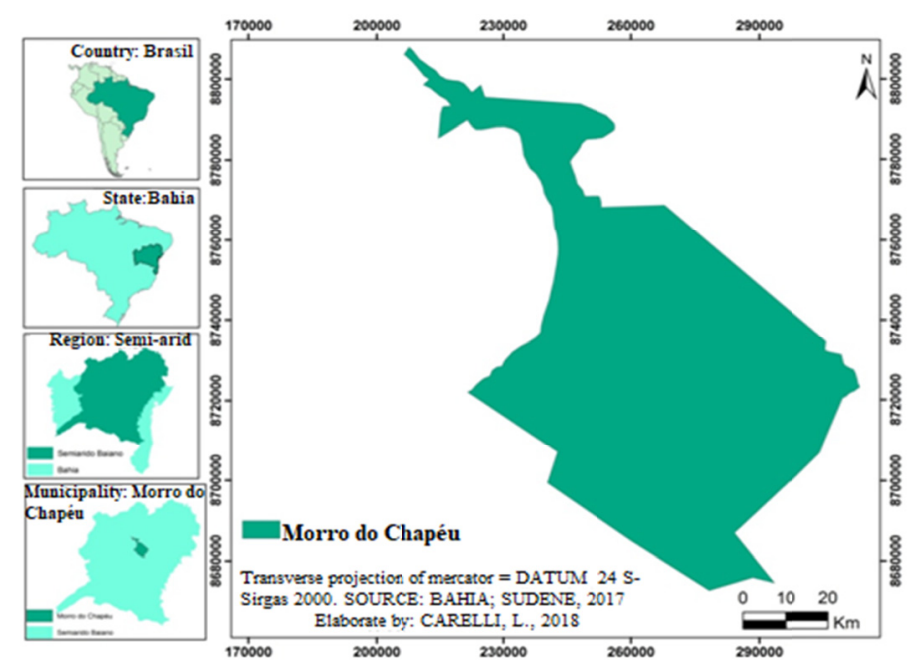

Figure 1. Geographic location of the municipality of Morro of Chapéu, Bahia, Brazil

Daily data of the maximum, minimum, and average temperatures, relative humidity, solar radiation, and corrected wind speed at $2 \mathrm{~m}$ height were used. The data was obtained from a conventional meteorological station, which belongs to the National Institute of Meteorology (INMET), during the period from January 1, 2000, to December 31, 2017. The period from 2000 to 2015 was used to adjust the parameters, while the years of 2016 and 2017, were assigned as independent data to validate the adjusted parameters.

Before performing the estimate analysis of ETo, an analysis was done to verify the data quality and to eliminate possible measurement errors. Following the methodology of Sales et al. (2018b), inconsistent data with the following criteria were excluded: minimum temperature below $0{ }^{\circ} \mathrm{C}$; maximum temperature above $40{ }^{\circ} \mathrm{C}$; maximum temperature lower than the minimum temperature for the same day; global solar radiation equal to zero, and global solar radiation greater than solar extraterrestrial radiation. Consequently, after these analyzes there were 6,401 days with consistent measurements, corresponding to $97.56 \%$ of the data.

From the acquired data, the ETo calculations were elaborated using alternative methods and the Penman-Monteith method (FAO-56 PM). The adjustment occurred by seasons, dividing the data into summer (December 22 to March 20), autumn (March 21 to June 21), winter (June 22 to September 22), and spring (September 23 to December 21). The equations used to calculate the ETo with different estimation methods are presented as follows: 


\subsection{Penman-Monteith (FAO-56 PM)}

The evapotranspiration estimation by the Penman-Monteith method was calculated using Equation 01 (Allen et al., 1998) (Equation 1).

$$
\mathrm{ETo}=\frac{0.408 \times \Delta \times(\mathrm{Rn}-\mathrm{G})+\gamma \times\left(\frac{900}{\mathrm{~T}_{\text {mean }}+273}\right) \times \mathrm{U}_{2} \times(\mathrm{es}-\mathrm{ea})}{\Delta+\gamma \times\left(1+0.34 \times \mathrm{U}_{2}\right)}
$$

Where, $\Delta$ is the slope of the vapor pressure curve $\left(\mathrm{kPa}^{\circ} \mathrm{C}^{-1}\right) ; \mathrm{R}_{\mathrm{n}}$ is the radiation balance $\left(\mathrm{MJ} \mathrm{m}^{-2} \mathrm{~d}^{-1}\right)$; $\mathrm{G}$ is the soil heat flux density $\left(\mathrm{MJ} \mathrm{m}^{2} \mathrm{~d}^{-1}\right) ; \gamma$ is the psychrometric constant $\left(\mathrm{kPa}^{\circ} \mathrm{C}^{-1}\right) ; \mathrm{T}_{\text {mean }}$ is the mean daily air temperature in ${ }^{\circ} \mathrm{C}$; $\mathrm{U}_{2}$ is the wind speed (daily average) at $2 \mathrm{~m}$ height; $\mathrm{e}_{\mathrm{s}}$ is the saturation vapor pressure ( $\mathrm{kPa}$ ); $\mathrm{e}_{\mathrm{a}}$ is the actual vapor pressure $(\mathrm{kPa})$.

\subsection{Camargo (CM)}

The Camargo Method (1971) is a simplification of the Thornthwaite method. This method has as main advantage, the use of only data of mean daily air temperature and extraterrestrial solar radiation (Equation 2).

$$
\mathrm{ETo}=\mathrm{A} \times \frac{\mathrm{R}_{\mathrm{a}}}{2.45} \times \mathrm{T}_{\text {mean }}
$$

Where, $A$ is a coefficient of the method; $R_{a}$ is extraterrestrial solar radiation $\left(M J m^{-2} d^{-1}\right) ; T_{\text {mean }}$ is mean air temperature in ${ }^{\circ} \mathrm{C}$.

\subsection{Hargreaves and Samani $(H S)$}

The model proposed by Hargreaves and Samani (1985) was developed for dry climate regions and is a simple method (Equation 3).

$$
\text { ETo }=\mathrm{A} \times \frac{\mathrm{R}_{\mathrm{a}}}{2.45} \times\left(\mathrm{T}_{\max }-\mathrm{T}_{\min }\right)^{\mathrm{C}} \times\left(\mathrm{T}_{\text {mean }}+\mathrm{B}\right)
$$

Where, $A$ and $B$ are coefficients of the method; $R_{a}$ is the extraterrestrial solar radiation $\left(\mathrm{MJ} \mathrm{m}^{-2} \mathrm{~d}^{-1}\right) ; \mathrm{T}_{\max }$ is daily maximum temperature $\left({ }^{\circ} \mathrm{C}\right) ; \mathrm{T}_{\min }$ is daily minimum temperature $\left({ }^{\circ} \mathrm{C}\right) ; \mathrm{T}_{\text {mean }}$ is daily mean temperature $\left({ }^{\circ} \mathrm{C}\right)$.

\subsection{Priestley and Taylor (PT)}

The Priestley and Taylor Method (1972) is a simplification of the Penman and Penman-Monteith method. Thus, this model has the advantage of requiring less input data (Equation 4$)$.

$$
\mathrm{ETo}=\mathrm{A} \times\left(\frac{\Delta}{\Delta+\gamma}\right) \times\left(\frac{\mathrm{R}_{\mathrm{n}}-\mathrm{G}}{2.45}\right)
$$

Where, $\gamma$ is the psychrometric constant $\left(\mathrm{kPa}^{\circ} \mathrm{C}^{-1}\right) ; \Delta$ is the slope of the vapor pressure curve $\left(\mathrm{kPa}^{\circ} \mathrm{C}^{-1}\right) ; \mathrm{R}_{\mathrm{n}}$ is the net radiation received by the reference crop $\left(\mathrm{MJ} \mathrm{mm} \mathrm{d}^{-1}\right)$; $\mathrm{G}$ is the soil heat flux density $\left(\mathrm{mm} \mathrm{d}^{-1}\right)$.

\subsection{Statistical Analysis}

The adjustment parameter was performed by minimizing the error square sum, obtained by comparing the estimated ETo between the alternative methods and the FAO-56 PM model. For this, the Solver application within the software Office Excel 2007® was used, besides the aid of the open source program R (R core team, 2016) to perform the statistics.

To analyze the results, the statistical indicators, root mean square error (RMSE in $\mathrm{mm} \mathrm{d}^{-1}$ ), coefficient of determination $\left(\mathrm{R}^{2}\right.$ ), systematic error (BIAS in $\mathrm{mm} \mathrm{d}^{-1}$ ), and Willmott's concordance index (Willmott et al., 1985), were used to evaluate the accuracy of the different models.

\section{Results and Discussion}

The values of the original and the adjusted coefficients for each of the evaluated methods can be visualized by season of the year, in relation to the FAO-56 PM standard method for the municipality of Morro do Chapéu, Bahia (Table 1). When evaluating the adjustment of each method per season of the year, it is observed that the values followed very close to each other, except for HS, in which the values of B coefficient ranged from 29.0 to 82.0. Sales et al. (2018b) when adjusting the HS method for the region of São Mateus, ES, found a value of B of 5.59 , which is lower than that found in this study. 
Table 1. Values of the original and adjusted parameters for the methods of Camargo (CM), Hargreaves and Samani (HS), and Priestley and Taylor (PT)

\begin{tabular}{|c|c|c|c|c|c|c|c|c|c|c|}
\hline \multirow{3}{*}{ Season } & \multicolumn{2}{|c|}{ CM } & \multicolumn{6}{|c|}{ HS } & \multicolumn{2}{|c|}{ PT } \\
\hline & \multirow{2}{*}{$\begin{array}{l}\text { Original } \\
\text { A }\end{array}$} & \multirow{2}{*}{$\begin{array}{l}\text { Adjusted } \\
\text { A }\end{array}$} & \multicolumn{3}{|c|}{ Original } & \multicolumn{3}{|c|}{ Adjusted } & \multirow{2}{*}{$\begin{array}{l}\text { Original } \\
\text { A }\end{array}$} & \multirow{2}{*}{$\begin{array}{l}\text { Adjusted } \\
\text { A }\end{array}$} \\
\hline & & & $\mathbf{A}$ & B & $\mathbf{C}$ & $\mathbf{A}$ & B & $\mathrm{C}$ & & \\
\hline Summer & 0.011 & 0.013 & 0.002 & 17.8 & 0.5 & 0.001 & 68.0 & 0.387 & 1.3 & 0.983 \\
\hline Autumn & 0.011 & 0.013 & 0.002 & 17.8 & 0.5 & 0.003 & 29.0 & 0.347 & 1.3 & 0.982 \\
\hline Winter & 0.011 & 0.013 & 0.002 & 17.8 & 0.5 & 0.002 & 43.7 & 0.391 & 1.3 & 0.970 \\
\hline Spring & 0.011 & 0.014 & 0.002 & 17.8 & 0.5 & 0.001 & 82.0 & 0.377 & 1.3 & 0.982 \\
\hline
\end{tabular}

Note. Values of original and adjusted parameters for the methods in the different analyzed seasons of the year.

In Figure 2, it is possible to observe the average behavior of the reference evapotranspiration per season of the year, for the original and adjusted parameters. It is notorious an underestimation of the CM and HS methods and overestimation of the ETo of the PT (Figure 2A) compared to the FAO-56 PM, especially in the stations with higher evapotranspiration demand, which in the municipality under study coincided with the spring and summer periods. However, the behavior of the different adjusted ETo methods presented behavior very close to the FAO-56 PM (Figure $2 \mathrm{~B}$ ). It is worth noting that the mean value of the methods during the seasons does not reveal the magnitude of the errors during the evaluated days, and other statistics are necessary in order to complete the evaluation, as observed in Table 2.
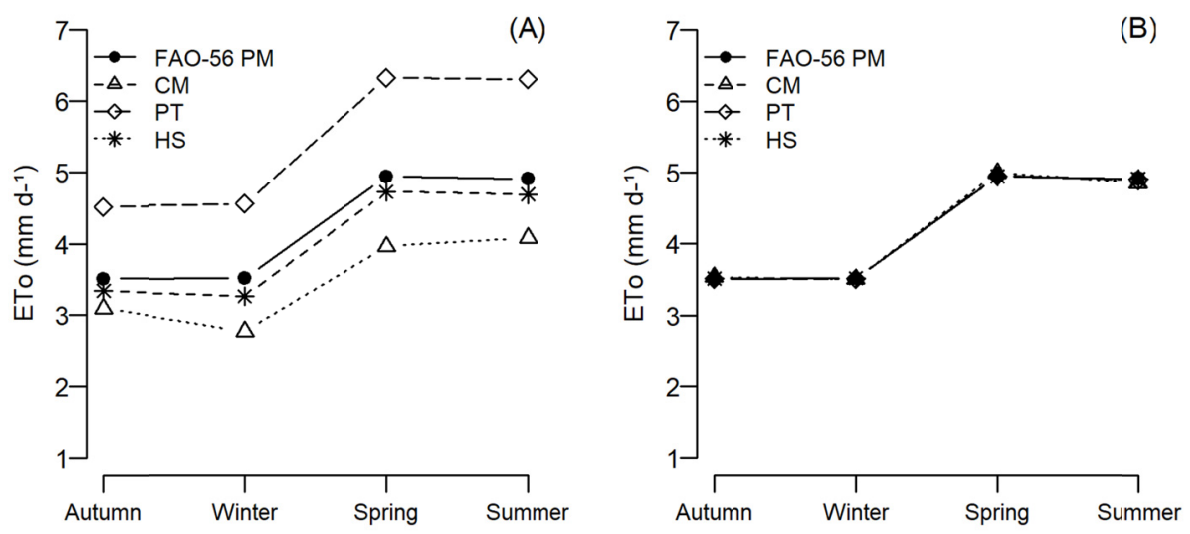

Figure 2. Estimation of the average reference evapotranspiration (ETo), obtained in the period from 2000 to 2015 in Morro do Chapéu, BA, for the seasons of the year. A: original; B: adjusted

The different methods used and their statistical results according to the evaluated season of the year are presented in Table 2. Among the evaluated methods, the original parameters HS and PT presented in general, a better coefficient of determination, presenting $\mathrm{R}^{2} \geq 0.98$ for all the seasons of the year.

The CM method showed a variation in the coefficient of determination from 0.63 to 0.89 , according to the analyzed seasons of the year, and it was notorious that the greatest penalty occurred in spring and summer. However, only using $\mathrm{R}^{2}$ as a criterion to visualize the quality of methods is not ideal, since this parameter does not establish the magnitude of the differences between a standard value and a predicted value by alternative models (Barros et al., 2009).

The systematic error shows the sub or overestimation of a model, so it is possible to observe that the PT method presented overestimated values in all analyzed stations, with values ranging from -1.02 to $-1.40 \mathrm{~mm} \mathrm{~d}^{-1}$, when compared to FAO-56 PM. On the other hand, the CM and HS methods, which use only the temperature as input variable, presented values that, were underestimated in all analyzed stations.

The HS probably underestimated the ETo because the municipality of Morro do Chapéu has a dry climate and a high wind speed $\left(\mathrm{U}_{2}>3 \mathrm{~m} \mathrm{~s}^{-1}\right)$. Since this method tends to underestimate ETo values under these conditions (Allen et al., 1998; Alencar et al., 2011). The authors Santos et al. (2016) also found underestimated values for 
the HS method in the Agreste Alagoano. However, they recommend the method for its use, since that adjustment of the equation is done.

For the CM model, it is expected that under aridity conditions, the method presents underestimate in relation to the FAO-56 PM (Fernandes et al., 2010). The high BIAS values observed with the CM method reflected higher RMSE values (Table 2), especially in the spring and summer seasons, which presented high errors with a low agreement between the data.

Table 2. Evaluation of the ETo estimates $\left(\mathrm{mm} \mathrm{d}^{-1}\right)$ obtained in the four seasons of the year from 2000 to 2015 , with different methods in relation to the standard method, FAO-56 PM, before (original) and after (adjusted) adjustment of the parameters

\begin{tabular}{|c|c|c|c|c|c|c|c|c|c|c|}
\hline \multirow{2}{*}{ Methods } & \multicolumn{4}{|c|}{ Original } & \multicolumn{4}{|c|}{ Adjusted } & \multirow[t]{2}{*}{ Dif $_{\text {RMSE }}$} & \multirow[t]{2}{*}{ Dif $_{d}$} \\
\hline & RMSE & BIAS & $\mathrm{R}^{2}$ & $\mathrm{~d}$ & RMSE & BIAS & $\mathrm{R}^{2}$ & $\mathrm{~d}$ & & \\
\hline \multicolumn{11}{|l|}{ Spring } \\
\hline $\mathrm{CM}$ & 1.06 & 0.989 & 0.63 & 0.36 & 0.41 & -0.050 & 0.63 & 0.76 & 65.00 & 52.63 \\
\hline HS & 0.29 & 0.214 & 0.98 & 0.94 & 0.06 & -0.002 & 0.99 & 0.99 & 23.00 & 5.05 \\
\hline PT & 1.39 & -1.386 & 0.99 & 0.51 & 0.09 & 0.010 & 0.99 & 0.99 & 130.00 & 48.48 \\
\hline \multicolumn{11}{|l|}{ Summer } \\
\hline $\mathrm{CM}$ & 0.90 & 0.829 & 0.71 & 0.34 & 0.35 & 0.050 & 0.70 & 0.74 & 55.00 & 54.05 \\
\hline HS & 0.27 & 0.218 & 0.98 & 0.94 & 0.05 & 0.008 & 0.99 & 0.99 & 22.00 & 5.05 \\
\hline PT & 1.40 & -1.396 & 0.99 & 0.48 & 0.07 & 0.010 & 0.99 & 0.99 & 133.00 & 51.51 \\
\hline \multicolumn{11}{|l|}{ Autumn } \\
\hline $\mathrm{CM}$ & 0.51 & 0.419 & 0.89 & 0.82 & 0.29 & -0.030 & 0.90 & 0.94 & 22.00 & 12.77 \\
\hline HS & 0.22 & 0.169 & 0.97 & 0.97 & 0.06 & -0.010 & 0.99 & 0.99 & 16.00 & 2.02 \\
\hline PT & 1.03 & -1.024 & 0.99 & 0.69 & 0.06 & -0.004 & 0.99 & 0.99 & 97.00 & 30.30 \\
\hline \multicolumn{11}{|l|}{ Winter } \\
\hline $\mathrm{CM}$ & 0.82 & 0.741 & 0.89 & 0.61 & 0.30 & 0.009 & 0.89 & 0.93 & 52.00 & 34.41 \\
\hline HS & 0.29 & 0.251 & 0.98 & 0.96 & 0.07 & 0.000 & 0.99 & 0.99 & 22.00 & 3.03 \\
\hline PT & 1.05 & -1.043 & 0.99 & 0.68 & 0.08 & 0.007 & 0.99 & 0.99 & 97.00 & 31.31 \\
\hline
\end{tabular}

Note. Root mean square error (RMSE $\mathrm{mm} \mathrm{d}^{-1}$ ); Coefficient of determination $\left(\mathrm{R}^{2}\right)$; Systematic error (BIAS mm $\left.\mathrm{d}^{-1}\right)$; Willmott's concordance index $(\mathrm{d}) ; \operatorname{Dif}_{\mathrm{RMSE}}=\left(\mathrm{RMSE}_{\text {orig }}-\mathrm{RMSE}_{\text {adj }}\right) \times 100 ; \mathrm{Dif}_{\mathrm{d}}=\left[\left(\mathrm{d}_{\text {adj }}-\mathrm{d}_{\text {orig }}\right) / \mathrm{d}_{\text {orig }}\right] \times 100$; BIAS $=$ ETo PM-EToAlternative $/ \mathrm{n}$.

The RMSE values found by the original HS were the lowest among the three evaluated methods, with values varying from 0.22 to $0.29 \mathrm{~mm} \mathrm{~d}^{-1}$, according to the evaluated season. Therefore, the potentiality of the HS method in the region was evident, since this method only uses air temperature, and yet it showed good results, with low RMSE values and high values of $d$. This result may be linked to the model's foundation, which was developed for semi-arid conditions in California, and Morro do Chapéu municipality is part of the semi-arid region of the State of Bahia (Bastos et al., 2012), conferring low rainfall indices and high temperatures, favoring the model.

It is observed in all methods that, the seasons of spring and summer were the ones that presented the biggest estimative errors of ETo. These stations represent the rainy season of the municipality, as well as the incidence of higher temperatures, suggesting that these meteorological variables may have provided greater errors to the methods used.

After adjusting the parameters (Table 2), the CM, HS, and PT methods had the errors (RMSE) of their estimates reduced from 16.00 to $133.00 \%$ ( $\left(\mathrm{Dif}_{\mathrm{RMSE}}\right.$ ). The PT method, although a simplified version of the FAO-56 PM method, was the most benefited by the adjustment, with RMSE ranging from $0,06 \mathrm{~mm} \mathrm{~d}^{-1}$ for autumn, to 0,09 $\mathrm{mm} \mathrm{d}^{-1}$ in spring. In other words, the adjustment reduced the error by more than $95 \%$ and increased the $\mathrm{d}$ index, in such a way to present values of 0.99 , for the four stations evaluated.

Among the methods that only use air temperature as an independent variable (CM and HS), it can be observed after the adjustment that the CM method obtained higher increases in the $\mathrm{d}$ index, with values varying from 
12.77 to $54.05\left(\mathrm{Dif}_{\mathrm{d}}\right)$. However, only in the seasons of autumn and winter, a d value greater than 0.90 was observed, while the HS obtained values of $d \geq 0.99$, during all seasons of the year.

The CM results followed the same trend identified by Hallal et al. (2017), when estimating the ETo daily, quinquidial, monthly, and seasons of the year for the climatic conditions of Pelotas, RS. Where was verified for the seasons of the year that the $\mathrm{d}$ index ranged from 0.54 to 0.78 . However, this method was classified by these authors as bad and poor performance for all seasons.

Although the adjustment benefited all methods, the CM presented higher RMSE values when compared to the other models, reaching $0.41 \mathrm{~mm} \mathrm{~d}^{-1}$ in the spring. Bad results in methods based only on air temperature have been reported in the literature, and the low temperature variation is indicated as the main cause (Fanay a Júnior et al., 2012; Santos et al., 2017; Sales et al., 2018b).

The HS method after the adjustment showed RMSE $\leq 0.07 \mathrm{~mm} \mathrm{~d}^{-1}$ and a high concordance index using only the air temperature as an independent variable. Silva et al. (2005) when working with the municipality of Petrolina, $\mathrm{PE}$, verified that it is possible to indicate the original HS method for the estimation of ETo. Since it presented satisfactory results when compared to the FAO-56 PM standard method.

Thus, such methods can be an alternative, since many study areas have simple meteorological stations, equipped only with sensors of rain and air temperature. However, their low accuracy must be taken into account at the time of its application, recognizing the limitation of each method.

For the validation of the adjusted methods, the RMSE error coefficient and the Wilmmott's concordance index were presented in Figures 2, 3, and 4. The values refer to the statistical performance of the different methods used for the daily estimation of ETo, during the years of 2016 and 2017, for the municipality of Morro do Chapéu, BA. When applying the ETo methods, with adjusted parameters in this study, for a series of independent climatic data, it was observed that there was a variation of 0.08 to $0.43 \mathrm{~mm} \mathrm{~d}^{-1}$ between the methods and the seasons of the year.

In Figure 3, it is noteworthy that the spring (A) and summer (B) seasons presented the greatest errors for CM, as well as the lowest values of Wilmmott's concordance index. However, even the autumn (C) and winter (D) seasons showed better values after calibration, where errors of 0.35 and $0.29 \mathrm{~mm} \mathrm{~d}^{-1}$ for the seasons were observed, respectively. Corroborating with Hallal et al. (2017), when estimating the ETo for the seasons of the year in Pelotas, verified that in spring and summer they had the highest standard error of estimate (EPE) (1.04 $\left.\mathrm{mm} \mathrm{d}^{-1}\right)$ and $\left(1.17 \mathrm{~mm} \mathrm{~d}^{-1}\right)$, respectively. It is verified that these stations for the municipality under study are characterized by increased rainfall and air temperature, which may contribute to the results found.

The Camargo method proved to be inefficient to estimate the ETo by seasons of the year in the municipality of Morro do Chapéu. Since it presented unsatisfactory results, with little agreement and high errors, mainly during the spring and summer. It should be noted that the Camargo method was initially proposed to determine the ETo for periods after seven days, which contributed to its low accuracy (Paz et al., 2018). Less precise results by the CM method were observed by Sales et al. (2018b), when adjusting different methods for the region of São Mateus, ES, with RMSE showing deviations of $24 \%$ and agreement of 0.81 when compared to FAO-56 PM. 

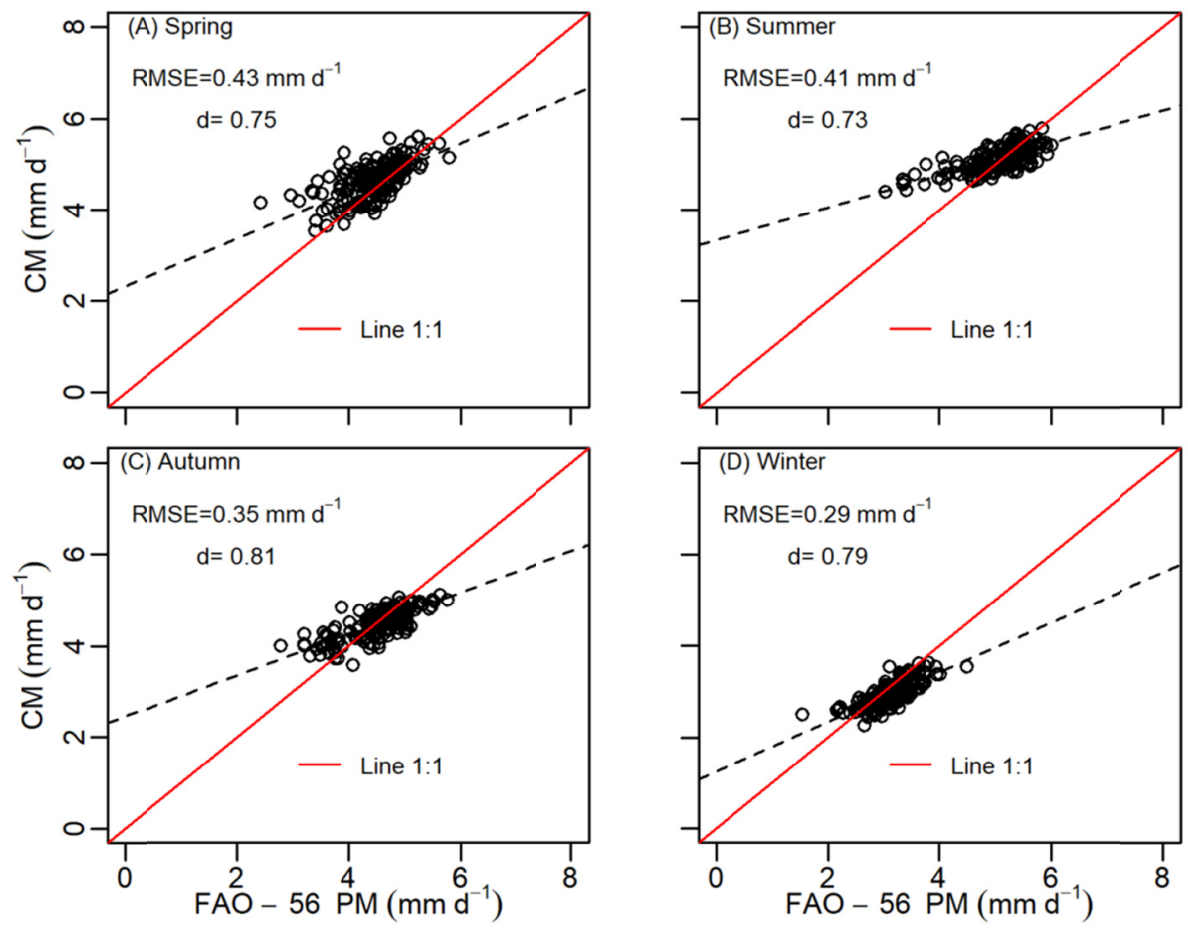

Figure 3. Reference evapotranspiration estimated by the Camargo (CM) adjusted method and Penman-Monteith FAO (FAO-56 PM), during the seasons of spring (A), summer (B), autumn (C), and winter (D) in the period of 2016 and 2017

The methods of HS and PT presented the best statistical values, with smaller errors, and better concordances between the data (Figures 4 and 5). It is observed in Figure 4 that there were no great variations in the seasons of the year for HS, with values below $0.15 \mathrm{~mm} \mathrm{~d}^{-1}$ for RMSE. The method of Hargreaves and Samani, unlike the Camargo method, tends to present better performance in conditions of lower cloudiness, since it was developed for semi-arid regions (Souza et al., 2011; Lucena et al., 2016).

In this way, the adjustment of this method to the local climatic conditions becomes important. The validated HS method (Figure 4) presented better results in relation to the same, without calibration (Table 2), with the regression line closer to the 1:1 comparison line.

This shows that the adjustment allowed an efficiency improvement of the reference evapotranspiration estimation during the seasons of the year. The same was observed by Paz et al. (2018) when adjusted this model on a daily scale in Formiga, Minas Gerais. For Ferronato et al. (2016), the adjusted HS method showed good results when estimating ETo, for all seasons of the year, when compared to the standard method of Penman-Monteith-FAO 56. 

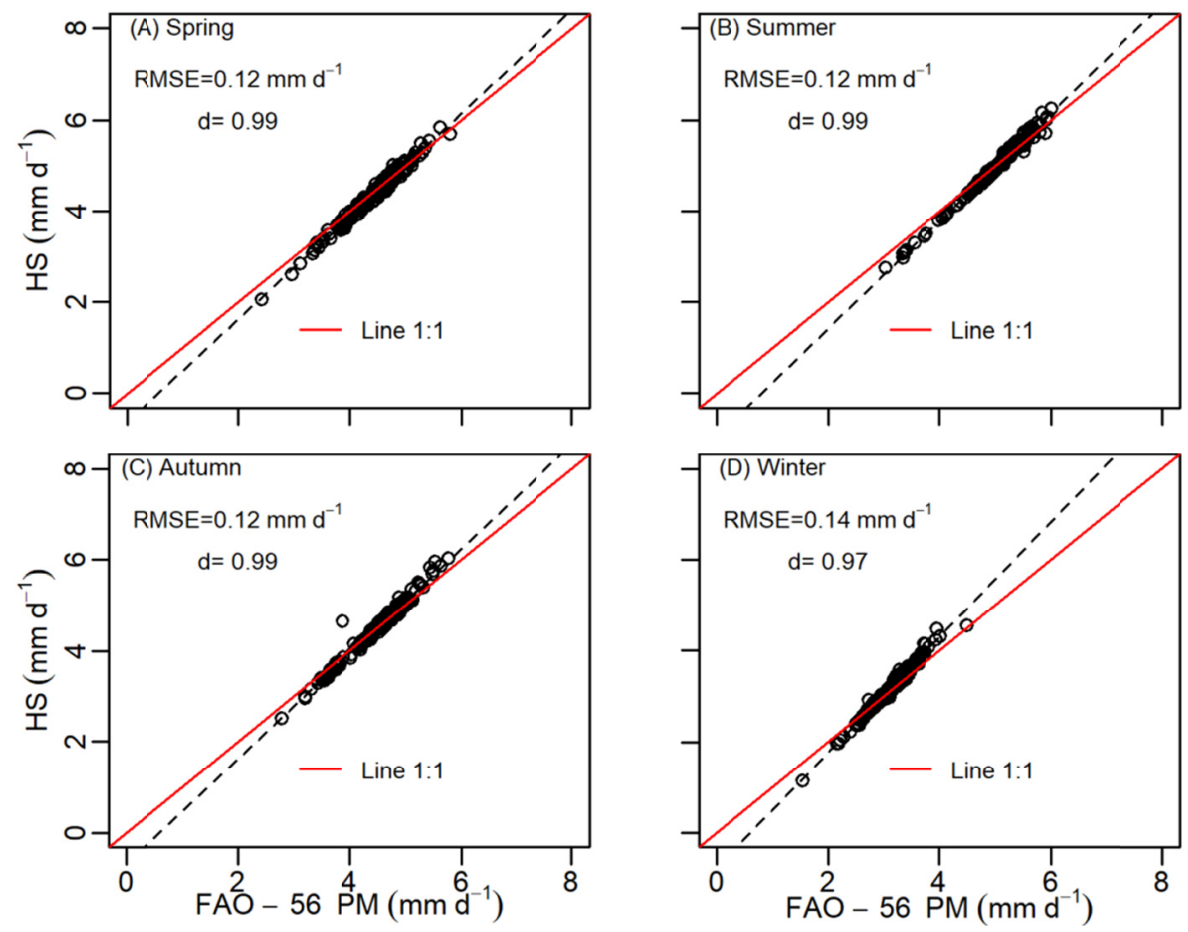

Figure 4. Reference evapotranspiration estimated by the methods Hargreaves and Samani (HS) adjusted and Penman-Monteith FAO (FAO-56 PM), during spring (A), summer (B), autumn (C), and winter (D) in the period of 2016 and 2017

When comparing the performance of the PT method with the FAO-56 PM method (Figure 5), it is observed a very consistent agreement between them. This is confirmed statistically by the RMSE values below $0.12 \mathrm{~mm} \mathrm{~d}^{-1}$ during the analyzed seasons and by the extremely small dispersion of the pairs ordered around the 1:1 line, with little influence of the annual seasonality in the validated values.

The original method presented high errors (Table 2), however, when adjusted, it obtained excellent results. One of the reasons why the PT method presented good results is due to the use of solar radiation as a predictive variable. Since this meteorological element is one of the most important in the estimation of ETo (Pandey et al., 2016).

Thus, the feasibility of recommending the adjusted PT method is evidenced when obtaining data of solar radiation from the meteorological station used to assess potential demand in a given locality. The same was observed by Nova et al. (2006) when adjusting the method of PT in Piracicaba, SP, being observed in the proposed model a very satisfactory performance, considering its high degree of precision and accuracy in the locality under study.

Borges Junior et al. (2012), evaluating six methods in the Garanhuns-PE region, which has a tropical humid climate for the spring-summer and autumn-winter periods, verified that the PT model performed better than the HS.

However, despite the good results found in the municipality of Morro do Chapéu, by the methods of HS and PT, their use is linked to the variables available in the station, since the PT needs radiation as an input variable to proceed with its calculation. In general, the data obtained indicate that the seasonal climatic variations in this part of the State of Bahia, Brazil, do not alter the accuracy of these methods (Figures 3, 4 and 5), except for CM, which presented slightly higher errors during summer and spring (Figures $3 \mathrm{~A}$ and $3 \mathrm{~B}$ ). 

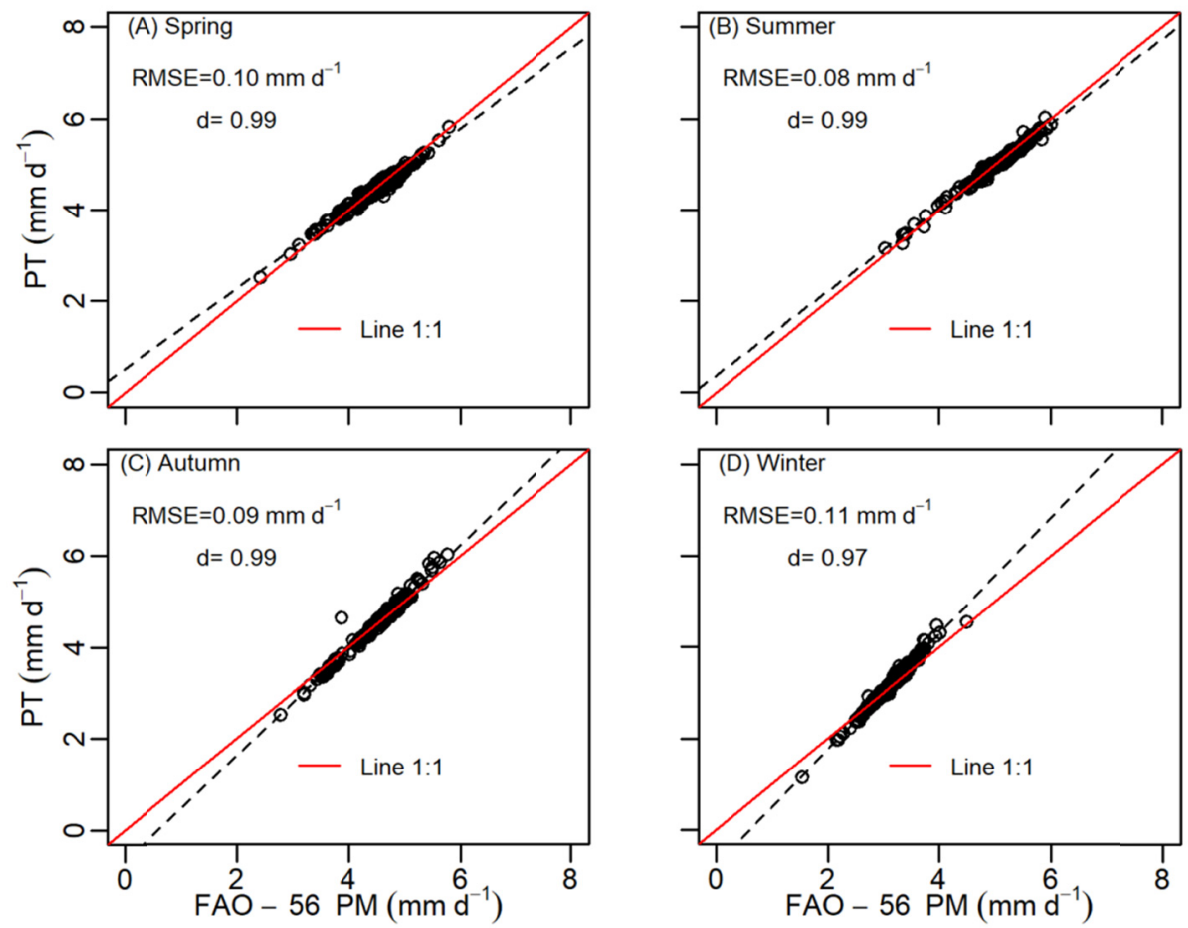

Figure 5. Reference evapotranspiration estimated by the Priestley and Taylor (PT) adjusted method and

Penman-Monteith FAO (FAO-56 PM) during the seasons spring (A), summer (B), autumn (C), and winter (D) in the period of 2016 and 2017

\section{Conclusion}

The use of the equations of Hargreaves and Samani, and, Priestley and Taylor adjusted for Morro do Chapéu, Bahia satisfactorily meet the estimation of ETo, independently of the season of the year. It can be recommended the use of these two methods for irrigation projects in the region when the availability of meteorological data is limited.

The Camargo method, even after adjustment, continued to present high estimation errors of ETo for the studied climatic conditions, compared to the FAO-56 PM method, reaching values above $0.40 \mathrm{~mm} \mathrm{~d}^{-1}$ in the seasons of spring and summer.

\section{References}

Allen, R. G., Pereira, L. S., Raes, D., \& Smith, M. (1998). Crop evapotranspiration: Guidelines for computing crop water requirements. FAO Irrigation and Drainage Paper, 56. FAO, Rome.

Alencar, L. P., Sediyama, G. C., Wanderley, H., Almeida, T. S., \& Delgado, R. C. (2011). Avaliação de métodos de estimativa da evapotranspiração de referência paratrês localidades no norte de minas gerais. Engenharia na Agricultura, 19(5), 437-449. https://doi.org/10.13083/1414-3984.v19n05a05

Bastos, C. A., \& Van Den Berg, C. (2012). Orchidaceae in Morro do Chapéu, Bahia, Brazil. Revista Rodriguésia, 63(4), 883-927. https://doi.org/10.1590/S2175-78602012000400010

Barros, V. R., Souza, A. P., Fonseca, D. C., \& Silva, L. B. D. (2009). Avaliação da evapotranspiração de referência na Região de Seropédica, Rio de Janeiro, utilizando lisímetro de pesagem e modelos matemáticos. Revista Brasileira de Ciências Agrárias, 4(2), 198-203. https://doi.org/10.5039/agraria.v4i2a13

Bezerra, J. R. C., Azevedo, P. V., Silva, B. B., \& Dias, J. M. (2010). Evapotranspiração e coeficiente de cultivo do algodoeiro BRS-200 Marrom, irrigado. Revista Brasileira de Engenharia Agrícola e Ambiental, 14(6), 625-632. https://doi.org/10.1590/S1415-43662010000600009

Borges Junior, J. C. F., Anjos, R. J., Silva, T. J. A., Lima, J. R. S., \& Andrade, C. L. T. (2012). Métodos de estimativa da evapotranspiração de referência diária para a microrregião de Garanhuns, PE. Revista Brasileira de Engenharia Agrícola e Ambiental, 16(4), 380-390. https://doi.org/10.1590/S1415-43662012 000400008 
Camargo, A. P. (1971). Balanço hídrico no Estado de São Paulo. Boletim, 116, 24.

Carvalho, D. F., Rocha, H. S., Bonomo, R., \& Souza, A. P. (2015). Estimativa da evapotranspiração de referência a partir de dados meteorológicos limitados. Revista Pesquisa Agropecuária Brasileira, 50(1). https://doi.org/10.1590/S0100-204X2015000100001

Fanaya Júnior, E. D., Silva Lopes, A., Oliveira, G. Q., \& Jung, L. H. (2012). Métodos empíricos para estimativa da evapotranspiração de referência para Aquidauana-MS. Revista Irriga,Botucatu, 17(4), 418-434. https://doi.org/10.15809/irriga.2012v17n4p418

Fernandes, D. S., Heinemann, A. B., Paz, R. L. F., \& Amorim, A. O. (2010). Evapotranspiração-Uma Revisão sobre os Métodos Empíricos. Embrapa Arroz e Feijão (p. 44).

Ferronato, A., Chig, A. D., Goulart, D. de B., Campelo Júnio, J. H., Pereira, L. C., \& Biudes, M. S. (2016). Métodos de estimativa da evapotranspiração de referência para Santo Antônio do Leverger-MT. Revista Ciência Agroambientais, 14(1), 110-118. https://doi.org/10.4322/rca.2322

Hallal, M. O. C., Schöffel, E. R., Brixner, B. F., \& Cunha, A. R. (2017). Métodos de estimativa da evapotranspiração de referência para Pelotas, Rio Grande do Sul. Revista CiênciaAgrária, 60(1), 1-10.

Hargreaves, G. H., \& Samani, Z. A. (1985). Reference crop evapotranspiration from temperature. Applied Engineering in Agriculture, 1(2), 96-99. https://doi.org/10.13031/2013.26773

Lucena, F. A. P., da Silva, E. M., de Albuquerque, R. A., Simeão, M., \& Pedrosa de Lucena, J. P. A. (2016). Comparação entre Métodos de Estimativa da Evapotranspiração de Referência no Município de Bom Jesus, PI. Revista Brasileira de Agricultura Irrigada, 10(3), 663-675. https://doi.org/10.7127/rbai.v10n300404

Lobão, J. S. B., Rocha, W. J. S. A. F., \& Silva, A. B. da S. (2011). Geoprocessamento na Modelagem da Vulnerabilidade Natural à Erosão no Município de Morro do Chapéu-Ba. Revista Brasileira de Cartografia, 63(1).

Pereira, L. S., Allen, R. G., Smith, M., \& Raes, D. (2014). Crop evapotranspiration estimation with FAO56: Past and future. Agricultural Water Management, 147, 4-20. https://doi.org/10.1016/j.agwat.2014.07.031

Nova, N. A. V., \& Perreira, A. B. (2006). Ajuste do Método de Priestley-Taylor às Condições Climáticas Locais. Revista Engenharia Agrícola, 26(2), 395-405. https://doi.org/10.1590/S0100-69162006000200007

Pandey, P. K., Dabral, P. P., \& Pandey, V. (2016). Evaluation of reference evapotranspiration methods for the northeastern region of India. International Soil and Water Conservation Research, 4(1), 56-67. https://doi.org/10.1016/j.iswcr.2016.02.003

Paz, L. R., \& Thebaldi, M. S. (2018). Estimativa da Evapotranspiração de Referência Diária em Formiga, MG, Brasil/ Estimate of Daily Reference Evapotranspiration at Formiga, MG, Brazil. Revista Brasileira de Engenharia de Biossistemas, 12(1), 7-17. https://doi.org/10.18011/bioeng2018v12n1p7-17

Priestley, C. H. B., \& Taylor, R. J. (1972). On the assessment of surface heat flux and evaporation using large-scale parameters. Monthly Weather Review, 100, 81-92. https://doi.org/10.1175/1520-0493(1972) 100\%3C0081:OTAOSH\%3E2.3.CO;2

R Core Team. (2016). R: A language and environment for statistical computing. R Foundation for Statistical Computing, Vienna, Austria. Retrieved from https://www.R-project.org

Sales, R. A., Louzada, J. M., Oliveira, E. C., Pineiro, M. A. B., \& Sales, R. A. (2016). Estimativa das necessidades hídricas do milho cultivado nas condições edafoclimáticasde São Mateus-ES. Enciclopédia Biosfera, 13(23), 598-609. https://doi.org/10.18677/Enciclopedia_Biosfera_2016_053

Sales, R. A., Ribeiro, W.R., Gonçalves, M. S., Oliveira, E. C., Gelcer, E. M., Pezzopane, J. E. M., \& Berilli, S. S. (2018a). A Comparative Study between Meteorological Data from Conventional and Automatic Weather Stations in Espírito Santo, Brazil. Journal of Experimental Agriculture International, 21(6), 1-12. https://doi.org/10.9734/JEAI/2018/40201

Sales, R. A., Oliveira, E. C., Lima, M. J. A., Gelcer, E. M., Santos. R. A., \& Lima, C. F. (2018b). Ajuste dos coeficientes das equações de estimativa da evapotranspiração de referência para São Mateus, ES. Revista Irriga, 23(1), 154-167. https://doi.org/10.15809/irriga.2018v23n1p154

Santos, C. S. dos, Santos, D. P. dos, Oliveira, W. J., Silva, P. F., Santos, M. A. L., \& Fontenele, A. J. P. B. (2016). Evapotranspiração de Referência e Coeficiente de Cultivo da Pimenteira no Agreste Alagoano. Revista Brasileira de Agricultura Irrigada, 10(5), 883- 892. https://doi.org/10.7127/rbai.v10n500458 
Santos, R. A., Santos, E. P., Sales, R. A., \& Santos, R. L. (2017). Estimativa da evapotranspiração de referência para o município de Feira de Santana (BA). Revista Brasileira de Agricultura Irrigada, 11(4), 1617-1626. https://doi.org/10.7127/rbai.v11n400557

Silva, V. de P. R., Belo Filho, A. F., Silva, B. B., \& Campos, J. H. B. C. (2005). Desenvolvimento de um sistema de estimativa da evapotranspiração de referência. Revista Brasileira de Engenharia Agrícola e Ambiental, 9(4), 547-553. https://doi.org/10.1590/S1415-43662005000400017

Srivastava, R. K., Panda, R. K., Chakraborty, A., \& Halder, D. (2018). Comparison of actual evapotranspiration of irrigated maize in a sub-humid region using four different canopy resistance based approaches. Agric. Water Manage, 202(1) 156-165. https://doi.org/10.1016/j.agwat.2018.02.021

Souza, A. P., Carvalho, D. F., Silva, L. B. D., Almeida, F. T., \& Rocha, H. S. (2011). Estimativas da evapotranspiração de referência em diferentes condições de nebulosidade. Revista de Pesquisa Agropecuária Brasileira, 46(3), 219-228. https://doi.org/10.1590/S0100-204X2011000300001

Tabari, H., \& Talaee, P. H. (2011). Local calibration of the Hargreaves and Priestley-Taylor equations for estimating reference evapotranspiration in aridandc old climates of Iran basedon the Penman-Monteith model. Journal of Hydrologic Engineering, 16(10), 837-845. https://doi.org/10.1061/(ASCE)HE.19435584.0000366

Tanaka, A. A., de Souza, A. P., Klar, A. E., Silva, A. C., \& Gomes, A. W. A. (2016). Evapotranspiração de referência estimada por modelos simplificados para o Estado do Mato Grosso. Revista Pesquisa Agropecuária Brasileira, 51(2), 91-104. https://doi.org/10.1590/S0100-204X2016000200001

Willmott, C. J., Ckleson, S. G., \& Davis, R. E. (1985). Statistics for evaluations and comparisons of models. Journal os Geophysical, 90(65), 8995-9005. https://doi.org/10.1029/JC090iC05p08995

\section{Copyrights}

Copyright for this article is retained by the author(s), with first publication rights granted to the journal.

This is an open-access article distributed under the terms and conditions of the Creative Commons Attribution license (http://creativecommons.org/licenses/by/4.0/). 